\title{
The ICT adoption in enterprises in the context of the sustainable information society
}

\author{
Ewa Ziemba \\ Faculty of Finance and Insurance \\ University of Economics in Katowice \\ 1 Maja 50, 40-287 Katowice, Poland \\ ewa.ziemba@ue.katowice.pl
}

\begin{abstract}
This study, part of an ongoing global study, aims to advance information society research and practice by examining and understanding the information and communication technologies (ICT) adoption in enterprises in the context of the sustainable information society (SIS). In this study, the ICT adoption is described by four components. i.e. outlay on ICT, information culture, ICT management, and ICT quality, whereas the sustainability is composed of ecological, economic, socio-cultural, and political sustainability. This study employs a quantitative approach to identify the levels of ICT adoption and sustainability in enterprises as well as investigate the correlation between these two constructs. The survey questionnaire was used and data collected from 394 enterprises were analyzed. The research findings reveal that there were significant statistical differences between the highest level of outlay on ICT and the lowest ones, namely the levels of ICT quality and ICT management. Moreover, the economic sustainability was at the highest level, whereas the lowest and similar levels were specific to ecological and political sustainability. Finally, it is investigated that the ICT quality, ICT management, and information culture have a significant impact on the sustainability, whereas the outlay on ICT does not have such an impact. This study advances the information society research and practice by measuring the ICT adoption, sustainability and correlation between them in the Polish enterprises.
\end{abstract}

\section{INTRODUCTION}

$\mathrm{T}$ he sustainable information society (SIS) is a new phase of information society development in which information and communication technologies (ICT) are becoming key enablers of sustainability [1]-[10]. Researchers and various organizations have explored the areas where the information society, sustainable development, and ICT come together, and identified some correlations between those concepts [11-17]. Overall, the SIS is a multidimensional concept encompassing environmental, economic, cultural, social, and political aspects, all of which could be strongly influenced by adopting ICT by society stakeholders, mainly enterprises, households, and public administration [10].

In general terms, enormous ICT potential for the SIS development can be approached from two angles: ICT as an industry and ICT as a tool [10]. As an industry, ICT have become a major economic driver in the hardware, software, telecommunications, and consulting services sectors. ICT as a tool can be used to transform and improve business, everyday life of people, and public governance.
ICT used as a tool to revolutionize business is examined in this study. Some researchers have identified ICT as one of the most important tools in building sustainable business practices [17] and supporting the success of businesses [18]. It is contended that ICT enable businesses to improve productivity, support innovation, reduce costs, increase the effectiveness of processes services, enhance the efficiency of business decision-making, respond to customers at a faster rate, and acquire new customers [14], [17]. Moreover, the ICT adoption in enterprises can yield benefits in environmental preservation by increasing energy efficiency and equipment utilization [4] as well as it can influence social development by making information available to all society stakeholders [7].

All these possibilities make ICT enablers of sustainability in several respects, i.e. environmental protection (ecological sustainability), economic growth (economic sustainability), socio-cultural development (socio-cultural sustainability), and governance (political sustainability) [10].

Following an extensive review of the literature, it did not uncover any deep studies to identify levels of ICT adoption and sustainability in enterprises as well as interpret how the ICT adoption in enterprises improves the SIS. Moreover, there is a lack of research on the SIS and correlations between the ICT adoption and sustainable development in less developed European countries, which are called transition economies [19]. The European transition economies are the former Eastern Bloc countries, which, since the early 1990s, have been undergoing transition from the command economy model to the free market model. We can identify the leaders and the followers of the transition process. In the first group there are: Poland, the Czech Republic, Hungary, Slovakia, Slovenia, Lithuania, Latvia, Estonia, Croatia, Romania and Bulgaria. The second group includes Belarus, Russia, Georgia, Moldova, Ukraine, Serbia and Montenegro.

In light of the above limitations, this paper focuses on exploring the ICT adoption and sustainability in enterprises. Its aims are to identify the levels of ICT adoption and sustainability in enterprises, and investigate the correlation between the two constructs.

The paper is structured as follows. Section I is an introduction to the subject. Section II states the theoretical background of ICT adoption and sustainability, and poses research questions. Section III describes the research 
methodology. Section IV presents the research findings on the levels of ICT adoption and sustainability in enterprises, and the correlations between the ICT adoption and sustainability. Section V provides the study's contributions, implications, and limitations as well as considerations for future investigative work.

\section{THEORETICAL BACKGROUND AND RESEARCH QUESTION}

\section{A. The ICT adoption}

ICT are defined as a diverse set of software and hardware, to perform together various functions of information creation, storing, processing, preservation and delivery, in a growing diversity of ways [20]. Based on works about the adoption and implementation of enterprise's information system, the adoption of ICT can be defined as ICT design, implementation, stabilization, and continuous improvement [21]. In this study, ICT adoption is understood as the whole spectrum of activities from the period when enterprises justify the need for adopting ICT until the period when enterprises experience the full potential of ICT and derive benefits from them [22].

Based on a stream of research, Ziemba [22] advanced a model, which categorized the adoption of ICT into four components: outlay on ICT (Out), information culture (Cul), ICT management (Man), and ICT quality (Qua). The component of outlay on ICT included the enterprises' financial capabilities and expenditure on the ICT adoption, as well as funding acquired by enterprises from the European funds. The information culture component embraced digital and socio-cultural competences of enterprises' employees and managers, constant improvement of these competences, personal mastery, and incentive systems encouraging employees to adopt ICT. The ICT management component comprised of the alignment between business and ICT, top management support for ICT projects in the entire ICT adoption lifecycle, implementation of law regulations associated with the ICT adoption, regulations on ICT and information security and protection. The ICT quality component consisted of the quality and security of back- and front-office information systems, quality of hardware, maturity of e-services, and adoption of ERP and BI systems. See Table 1 for the description of each ICT adoption component. The construct asserted that the four components were interrelated and critical to the design of the ICT adoption in enterprises in the context of the SIS.

\section{B. The sustainability}

The definition of sustainable development [23] was, in this paper, taken as a basis for the conceptualization and operationalization of sustainability. According to Schauer [7], sustainable development has four dimensions which are ecological, social, economic and cultural sustainability. In a further study, Ziemba [22] proposed an expanded sustainability which included four sustainability components, i.e. ecological, economic, socio-cultural, and political. Regarding businesses, the sustainability components are [22]:

TABLE I.

PRIMARY VARIABLES OF ICT ADOPTION AND SUSTAINABILITY CONSTRUCTS

\begin{tabular}{|c|c|c|c|c|c|}
\hline \multicolumn{4}{|c|}{ Primary variables of the ICT adoption construct } & \multicolumn{2}{|c|}{$\begin{array}{l}\text { Primary variables of the sustainability } \\
\text { construct }\end{array}$} \\
\hline Out1 & Financial capabilities & Man16 & ICT project team & Ecl1 & Sustainability in ICT \\
\hline Out2 & Expenditure on ICT & Man17 & Top management support & Ecl2 & Sustainability by ICT \\
\hline Out3 & $\begin{array}{l}\text { Funding acquired from the European } \\
\text { funds }\end{array}$ & Man18 & Management concepts adoption & Eco3 & Cost reduction \\
\hline Cul4 & Managers' ICT competences & Man19 & Information security regulations & Eco4 & Sales growth \\
\hline Cul5 & Employees' ICT competences & Man20 & ICT regulations & Eco5 & Product development \\
\hline Cul6 & Managers' permanent education & Man21 & ICT public project & Eco6 & Effective and efficient management \\
\hline Cul7 & Employees' permanent education & $\operatorname{Man22}$ & Competitive ICT market & Eco7 & $\begin{array}{l}\text { Effective and efficient customer } \\
\text { service }\end{array}$ \\
\hline Cul8 & Employees' personal mastery & Qua23 & ICT infrastructure quality & Eco8 & Effective and efficient work \\
\hline Cul9 & $\begin{array}{l}\text { Managers' socio-cultural } \\
\text { competences }\end{array}$ & Qua24 & Back-office system quality & Eco9 & $\begin{array}{l}\text { Acquiring new customers and } \\
\text { markets }\end{array}$ \\
\hline Cul10 & $\begin{array}{l}\text { Employees' socio-cultural } \\
\text { competences }\end{array}$ & Qua25 & Front-office system quality & Eco10 & $\begin{array}{l}\text { Increasing customer } \\
\text { satisfaction/loyalty }\end{array}$ \\
\hline Cul11 & Employees' creativity & Qua26 & Back-office system security & Soc11 & Competence extension \\
\hline Cul12 & Incentive systems & Qua27 & Front-office system security & Soc12 & Working environment improvement \\
\hline Man13 & $\begin{array}{l}\text { Alignment between business } \\
\text { strategy and ICT }\end{array}$ & Qua28 & E-service maturity levels & Soc13 & Increasing security \\
\hline Man14 & Supporting business models by ICT & Qua29 & ERP adoption & Soc14 & Reducing social exclusion \\
\hline Man15 & ICT management procedure & Qua30 & BI adoption & Pol15 & E-democracy \\
\hline-- & -- & --- & --- & Pol16 & E-public services \\
\hline
\end{tabular}

Source: on the basis of [22]. 
- Ecological sustainability (Ecl) is the ability of enterprises to maintain rates of renewable resource harvest, pollution creation, and non-renewable resource depletion by means of conservation and proper use of air, water, and land resources [24], [25];

- Economic sustainability (Eco) of enterprises means that enterprises can gain competitive edge, increase their market share, and boost shareholder value by adopting sustainable practices and models. Among the core drivers of a business case for sustainability are: cost and cost reduction, sales and profit margin, reputation and brand value, innovative capabilities [14], [15];

- Socio-cultural sustainability (Soc) is based on the socio-cultural aspects that need to be sustained, e.g. trust, common meaning, diversity as well as capacity for learning and capacity for self-organization [26]. It is seen as dependent on social networks, making community contributions, creating a sense of place and offering community stability and security [27], [28]; and

- Political sustainability (Pol) must rest on the basic values of democracy and effective appropriation of all rights. It is related to the engagement of enterprises in creating democratic society [28].

Table 1 presents the description of each sustainability component.

\section{Correlations between ICT adoption and sustainability}

Some studies show that ICT adoption affects the sustainable development. Schauer [7] stated that ICT can contribute to the sustainable development, especially to ecological, social, cultural, and economic sustainability. Hilty and others asserted that information systems can facilitate the sustainable development by creating the kind of economic activity that harmonizes nature with human and social welfare in the long term [29]. Johnston referred to the ICT impact on the SIS, pointing out to the need for "greater synergy between RTD (research and technology development), regulation and deployment actions; greater investment in more effective public services, notably for health care and education, as well as for administrations; and more active promotion of 'eco-efficient' technologies and their use" [30, p. 203].

Curry and Donnellan [12] proposed the Sustainable ICT Capability Maturity Framework (SICT-CMF). The framework provides a comprehensive value-based model for organizing, evaluating, planning, and managing sustainable ICT capabilities. Using the framework, organizations can assess the maturity of their SICT capability and systematically improve capabilities in a measurable way to meet the sustainability objectives including reducing environmental impacts and increasing profitability. However, the SICT-CMF goes beyond ICT to encompass other factors such as alignment with corporate sustainability strategy, project planning, developing expertise, culture, and governance.

\section{Research questions}

According to Ziemba [22], the SIS is a multidimensional concept encompassing two constructs: the ICT adoption and sustainability, as well as correlations between them. The sustainability construct embracing the environmental, economic, socio-cultural, and political sustainability can be strongly influenced by the ICT adoption consisting of the outlay on ICT, information culture, ICT management, and ICT quality.

In the previous study Ziemba [22] assessed the quality of the two constructs by examining the construct reliability [31], convergent validity [32], [33], and discriminant validity [32], [34]. The following measures were calculated: the loadings of each item of each component, composite reliability (CR) of all components, average variance extracted (AVE) of all components, Cronabch's Alpha of all components, correlations between the components, the square root of AVE for each component. Overall, the results successfully established the reliability, convergent validity, and discriminant validity of the proposed constructs and their components [22].

The present study examines the SIS in the context of Polish enterprises and focuses on addressing the following research question:

RQ1: What is the level of ICT adoption in Polish enterprises?

RQ2: What is the level of sustainability in Polish enterprises?

RQ3: How does the ICT adoption influence the sustainability in Polish enterprises?

\section{RESEARCH METHODOLOGY}

\section{A. Research instrument}

The Likert-type instrument (questionnaire) was developed that consisted of two SIS constructs: the ICT adoption and sustainability. The task of respondents was to assess the primary variables describing:

- The four components of the ICT adoption construct, i.e. outlay on ICT (Out), information culture (Cul), ICT management (Man), and ICT quality (Qua) (Table 1). The respondents answered the question: Using a scale of 1 to 5, state to what extent do you agree that the following situations and phenomena result in the efficient and effective ICT adoption in your enterprise? The scale's descriptions were: 5 strongly agree, 4 - rather agree, 3 - neither agree nor disagree, 2 - rather disagree, 1 - strongly disagree; and

- The four components of the sustainability construct, i.e. ecological (Ecl), economic (Eco), socio-cultural (Soc), and political sustainability (Pol) (see Table 1). 
The respondents answered the question: Using $a$ scale of 1 to 5, evaluate the following benefits for your enterprise resulting from the efficient and effective ICT adoption? The scale's descriptions were: 5 - strongly large, 4 - rather large, 3 - neither large nor disagree, 2 - rather small, 1 - strongly small.

\section{B. Research subjects and procedures}

In April 2016, the pilot study was conducted to verify the survey questionnaire. Ten experts participated in the study, i.e. five researchers in business informatics and five managers from five enterprises - leaders in the ICT application. Finishing touches were put into the questionnaire, especially of a formal and technical nature. No substantive amendments were required.

The subjects in the study were enterprises from the Silesian Province in Poland. The choice of this region was driven by the fact of its continuous and creative transformations related to restructuring and reducing the role of heavy industry in the development of research and science, supporting innovation, using know-how and transferring new technologies, as well as increasing importance of services. In response to the changing socioeconomic and technological environment intensive work on the development of the information society has been undertaken in the region for several years. In the next development strategies of the information society it was and is assumed that the potential of the region, especially in the design, provision and use of advanced information and communication technologies will be increased [35]. All this means that the results of this research can be reflected in innovative efforts to build a sustainable information society in the region and, at the same time, constitute a modus operandi for other regions throughout the country and other countries.

Selecting a sample is a fundamental element of a positivistic study [36]. The stratified sampling and snowball sampling were therefore used to obtain the sample that can be taken to be true for the whole population. The following strata were identified based on enterprise's size (defined in terms of the number of employees).

The subjects were advised that their participation in completing the survey was voluntary. At the same time, they were assured anonymity and guaranteed that their responses would be kept confidential.

\section{Data collection}

Having applied the Computer Assisted Web Interview and employed the SurveyMonkey platform, the survey questionnaire was uploaded to the website. The data were collected during a two-month period of intense work, between 12 May 2016 and 12 July 2016. After screening the responses and excluding outliers, there was a final sample of 394 usable, correct, and complete responses. The sample ensured that the error margin for the $97 \%$ confidence interval was $5 \%$.

Table 2 provides details about enterprise's size, type of the business activities, and economy sector.

TABLE II.

ANALYSIS OF ENTERPRISES PROFILES ( $\mathrm{N}=394)$

\begin{tabular}{|l|c|c|}
\hline Characteristics & Frequency & Percentage \\
\hline Number of employees & 78 & $19.80 \%$ \\
\hline 250 and above (large) & 83 & $21.07 \%$ \\
\hline $50-249$ (medium) & 122 & $30.96 \%$ \\
\hline $10-49$ (small) & 111 & $28.17 \%$ \\
\hline less than 10 (micro) & 27 & $6.85 \%$ \\
\hline Economy sector & 83 & $21.07 \%$ \\
\hline $\begin{array}{l}\text { I sector - producing raw material and } \\
\text { basic foods }\end{array}$ & 46 & $11.68 \%$ \\
\hline $\begin{array}{l}\text { II sector - manufacturing, processing, } \\
\text { and construction }\end{array}$ & 238 \\
\hline $\begin{array}{l}\text { III sector - providing services to the } \\
\text { general population and to } \\
\text { businesses }\end{array}$ & 136 & $34.52 \%$ \\
\hline $\begin{array}{l}\text { IV sector - including intellectual } \\
\text { activities }\end{array}$ & 258 & $65.48 \%$ \\
\hline Business activities & & \\
\hline \begin{tabular}{l} 
ICT (manufacturing, trade, services) \\
\hline No ICT
\end{tabular} &
\end{tabular}

Source: own elaboration.

\section{Data analysis}

The data was stored in Microsoft Excel format. Using Statistica package and Microsoft Excel, and analyzed in two stages. The first stage assessed the levels of the ICT adoption and sustainability construct, and the second stage examined the significance of construct correlations and provided regression analysis.

In the first stage, the descriptive statistical analysis was employed to describe the levels of the ICT adoption and sustainability in enterprises. The following statistics were calculated: mean, median (MDN), first quartile (Q25), third quartile (Q75), mode, variance (VAR), standard deviation (SD), coefficient of variation (CV), skewness (SK), and coefficient of kurtosis (CK). Additionally, the analysis of variance (Anova Kruskala-Wallisa) was used to determine if there were statistically significant differences between distributions of scores for the ICT adoption components and sustainability components.

In the second stage, the correlation and regression analysis [37] were used to estimate the correlations between a dependent variable and one or more independent variables. The coefficient of determination, denoted $\mathrm{R}^{\wedge} 2$ and advanced $\mathrm{R}^{\wedge} 2$, determines the productiveness of the proposed theoretical model. Falk and Miller [38] recommended that 
$\mathrm{R}^{\wedge} 2$ values should be equal to or greater than 0.10 in order to be deemed adequate for the variance explained of a particular endogenous components (sub-constructs).

\section{RESEARCH FINDINGS}

\section{A. The level of ICT adoption in enterprises}

In order to answer the research question RQ1: What is the level of ICT adoption in Polish enterprises?, a detailed descriptive analysis was conducted. The results are presented in Table 3.

It has been found that the average levels of ICT adoption components ranged from 3.58 to 3.78 (on a 5-point scale from 1.00 to 5.00). Median values were in the range between 3.60 and 4.00. On average, the level of outlay on ICT was the highest, followed by the level of information culture. The levels of ICT management and ICT quality were the lowest. The levels of the ICT adoption components were above their average levels in most enterprises.

The values of h-Kruskala-Wallisa $\mathrm{H}(3, \mathrm{~N}=1576)=17.980$ and $\mathrm{p}=0.000$ ) and Chi-square statistic (Chi-square $=6.669$, $\mathrm{df}=3, \mathrm{p}=0.083$ ), and finally post-hoc analysis confirmed significant differences between the distribution of scores for the ICT outlay and the distributions of scores for the ICT management $(p=0.001)$ and ICT quality $(p=0.008)$.

\section{B. The level of sustainability in enterprises}

In order to answer the research question $R Q 1$ : What is the level of sustainability in Polish enterprises?, a detailed descriptive analysis was conducted. The results are presented in Table 3.

It has been found that the average levels of sustainability components ranged from 3.44 to 3.68 (on a 5-point scale from 1.00 to 5.00). Median values were in the range between 3.50 and 3.75. On average, the level of economic sustainability was the highest, whereas the levels of ecological and political sustainability were the lowest. The levels of the sustainability components were above their average levels in most enterprises.

The values of h-Kruskala-Wallisa $(\mathrm{H}(3, \mathrm{~N}=1576)=13.731$, $\mathrm{p}=0.003$ ) and (Chi-square=9.369, $\mathrm{df}=3, \mathrm{p}=0.025)$, and finally post-hoc analysis confirmed significant differences between the distributions of scores for the economic sustainability and the distributions of scores for the ecological $(\mathrm{p}=0.009)$ and political $(\mathrm{p}=0.010)$ sustainability.

\section{The contribution of ICT adoption to sustainability}

Table 4 shows the results of the correlations between:

- the ICT adoption components and the components of the sustainability; and

- the ICT adoption components and the total sustainability construct (Y).

TABLE IV.

CORRELATIONS AMONG COMPONENTS OF ICT ADOPTION AND THE TOTAL SUSTAINABILITY AND ITS COMPONENTS

\begin{tabular}{|l|l|l|l|r|r|}
\hline Components & Ecl & Eco & Soc & \multicolumn{1}{c|}{ Pol } & Y \\
\hline Out & 0.317 & 0.350 & 0.355 & $\begin{array}{r}0.256 \\
\mathrm{p}=0.184\end{array}$ & 0.395 \\
\hline Cul & 0.402 & 0.529 & 0.527 & 0.337 & 0.572 \\
\hline Man & 0.438 & 0.596 & 0.604 & 0.442 & 0.656 \\
\hline Qua & 0.503 & 0.603 & 0.616 & 0.398 & 0.667 \\
\hline
\end{tabular}

Source: own elaboration.

The correlation coefficients for the components of ICT adoption and the components of sustainability were significantly different from zero $(p=0.000<0.05=\alpha)$, with the exception of one correlation between the outlay on ICT and the political sustainability $(\mathrm{p}=0.184)$. In all cases there was a positive linear correlation. In addition, all components of the ICT adoption construct had a significant association

TABLE III.

THE LEVELS OF ICT ADOPTION AND SUSTAINABILITY IN ENTERPRISES

\begin{tabular}{|l|c|c|c|c|c|c|c|c|c|}
\hline Component & Mean & Q25 & MDN & Q75 & VAR & SD & CV in \% & SK & CK \\
\hline ICT adoption components \\
\hline Out & 3.78 & 3.33 & 4.00 & 4.33 & 0.71 & 0.84 & 22.33 & -0.78 & 0.35 \\
\hline Cul & 3.71 & 3.22 & 3.78 & 4.33 & 0.57 & 0.75 & 20.32 & -0.46 & -0.35 \\
\hline Man & 3.58 & 3.10 & 3.60 & 4.20 & 0.62 & 0.79 & 22.07 & -0.55 & -0.17 \\
\hline Qua & 3.60 & 3.00 & 3.75 & 4.25 & 0.74 & 0.86 & 23.95 & -0.56 & -0.22 \\
\hline \multicolumn{7}{|l|}{ Sustainability components } \\
\hline Ecl & 3.44 & 3.00 & 3.50 & 4.00 & 1.03 & 1.01 & 29.48 & -0.40 & -0.58 \\
\hline Eco & 3.68 & 3.25 & 3.75 & 4.25 & 0.62 & 0.79 & 21.38 & -0.78 & 0.65 \\
\hline Soc & 3.51 & 3.00 & 3.75 & 4.25 & 0.78 & 0.88 & 25.14 & -0.46 & -0.35 \\
\hline Pol & 3.44 & 3.00 & 3.50 & 4.00 & 1.02 & 1.01 & 29.41 & -0.47 & -0.47 \\
\hline
\end{tabular}

Source: own elaboration. 
with the total sustainability construct (Y). The ICT management and ICT quality were correlated strongly with the sustainability. The moderate correlation was between the information culture and the sustainability, whereas there was a weak correlation between the outlay on ICT and the sustainability.

The correlations analysis was sought into the linear regression. In the first step of building the regression model, the following results were established. For the component of outlay on ICT, $\mathrm{p}$-value $(\mathrm{p}=0.557)$ was higher than the accepted level of significance $(\alpha=0.05)$. There is not enough evidence at the 0.05 significance level to conclude that there is a linear relationship between the level of outlay on ICT and the level of sustainability in the examined population. Therefore, this component was removed from the regression model and then the correct model was received. The results of estimations are presented in Table 5 .

Three components of the ICT adoption construct, i.e. the information culture, ICT management, and ICT quality explained $50 \%$ of the variance in the sustainability $(\mathrm{F} 3.390=131.98 ; \mathrm{p}<0.0000)$. These components predicted the sustainability significantly well. The examination of coefficients indicated that the components had a positive significant impact on the sustainability. The effects of the ICT quality and ICT management were stronger than of the information culture.

Then, the relationship between the ICT adoption and sustainability in the information society may be written:

\section{$\hat{\mathbf{Y}}=1.037+0.161 * \mathrm{Cul}+0.232 * \mathrm{Man}+0.311 * \mathrm{Qua}$}

where:

$\hat{\mathbf{Y}} \mathbf{p}$ - the theoretical level of sustainability in the information society in the context of enterprises, including balancing ecological, economic, socio-cultural, and political sustainability;

Cul - the level of information culture in enterprises;

Man - the level of ICT management in enterprises; and

Qua - the level of ICT quality in enterprises.

Generally, the estimated model is correct and there is no reason to reject it. It allows understanding of the ICT adoption contribution to the sustainability of the information society in the context of enterprises. It gives an answer to the question - whether the growth in levels of outlay on ICT, information culture, ICT management, and ICT quality in enterprises determines an increase in the level of sustainability of the information society. The above results successfully established the significant and positive contribution of information culture, ICT management, and ICT quality to the sustainability in the SIS.

\section{V.CONCLUSIONS}

\section{A. Research contribution}

This work contributes to existing research on the SIS, in particular the contribution of ICT adoption to the sustainability by:

- indicating and describing the level of ICT adoption in enterprises, especially the levels of the outlay on ICT, information culture, ICT management, and ICT quality;

- $\quad$ indicating and describing the level of sustainability in enterprises, especially the levels of ecological, economic, socio-cultural, and political sustainability; and

- investigating how the ICT adoption in enterprises, i.e. the outlay on ICT, information culture, ICT management, and ICT quality contribute to the sustainability comprising its four types, i.e. ecological, economic, socio-cultural, and political.

Firstly, this study indicated significant statistical differences in the level of outlay on ICT and the levels of ICT quality and ICT management in the Polish surveyed enterprises. On average, the outlay on ICT was at the highest level, whereas the lowest and similar levels were specific to ICT management and ICT quality. It means that enterprises should improve ICT management and ICT quality.

Secondly, the outcomes showed significant statistical differences in the level of economic sustainability and the levels of ecological and political sustainability in the Polish surveyed enterprises. On average, the economic sustainability was at the highest level, whereas the lowest and similar levels were specific to ecological and political sustainability. It means that enterprises reap more economic benefits than ecological and political benefits from adopting ICT.

Thirdly, it was indicated that the information culture, ICT management, and ICT quality significantly and positively contribute to the sustainability in the SIS. However, the effects of the ICT quality and ICT management were stronger than of the information culture.

With regard to the presented results, it is reasonable to conclude that this study expands the existing research on the SIS provided by Schauer [7], Fuchs [1], [2], Hilty et al. [4], [5], Guillemette, Paré [14, [15], and Curry and Donnellan [12], [13].

\section{B. Research implication for research and practice}

The research findings of this study can be used by scholars to improve and expand the research on the SIS. Researchers may use the proposed methodology to do similar analyses with different sample groups in other countries, and many comparisons between different countries can be drawn. Moreover, the methodology constitutes a very comprehensive basis for identifying the levels of ICT adoption and sustainability, as well as the correlations 
between the two constructs, but researchers may develop, verify and improve this methodology and its implementation.

This study offers several implications for enterprises. They may find the results appealing and useful in enhancing the adoption of ICT, experiencing the full potential of ICT and deriving various benefits from the ICT adoption. The findings suggest some framework comprising various kinds of benefits like ecological, economic, socio-cultural, and political that can be obtained thanks to the ICT adoption. In addition, they recommend some guidelines on how to effectively and efficiently adopt ICT in order to obtain those benefits. It is evident from the findings that enterprises should pay utmost attention to the improvement of information culture, ICT management, and ICT quality. In particular, this research can be largely useful for the transition economies in Central and Eastern Europe. This is because the countries are similar with regard to analogous geopolitical situation, their joint history, traditions, culture and values, the quality of ICT infrastructure, as well as building democratic state structures and a free-market economy, and participating in the European integration process.

All in all, the research results might provide a partial explanation to the issue of how enterprises can participate in the creation of sustainable development and sustainable information society.

\section{Research limitations and future works}

As with many other studies, this study has its limitations. First, the ICT adoption and sustainability constructs are new constructs that have yet to be further explored and exposed to repeated empirical validation. Second, the sample included Polish enterprises only, especially from the Silesian Province. The study sample precludes statistical generalization of the results from Silesian enterprises to Polish enterprises. However, early research into the success factors for and the level of adopting ICT in Poland [39] indicated that there is no difference between Silesian enterprises and other Polish enterprises. Therefore, these research findings cannot be limited only to the Silesian enterprises and can be generalized to Polish enterprises. After all, caution should be taken when generalizing the findings to other regions and countries. Finally, the research subjects were limited to enterprises and it is therefore only the viewpoint of enterprises toward the ICT adoption for achieving the sustainability in the information society. Caution should be taken when generalizing the findings to the SIS.

Additional research must be performed to better understand the SIS, the ICT adoption and sustainability construct, and the correlations between the ICT adoption and sustainability. First, the further validation of the levels of ICT adoption and sustainability should be carried out for a larger sample comprising enterprises from different Polish provinces. Second, the methodology of the ICT adoption, sustainability, and SIS measurement should be explored in greater depth. A composite index for the SIS with subindexes of ICT adoption and sustainability in enterprises should be explored.

\section{REFERENCES}

[1] Ch. Fuchs, "Sustainable information society as ideology (part I)," Informacion Tarsadalom, vol. 9, no 2, pp. 7-19, 2009.

[2] Ch Fuchs, "Sustainable information society as ideology (part II)," Informacion Tarsadalom, vol. 9, no 3, pp. 27-52, 2009.

[3] Ch. Fuchs, "Theoretical foundations of defining the participatory, cooperative, sustainable information society," Communication \& Society, vol. 13, no 1, pp. 23-47, 2010.

[4] L.M. Hilty and B. Aebischer, "ICT for sustainability: An emerging research field," Advances in Intelligent Systems and Computing, vol. 310, pp. 1-34, 2015.

[5] L.M. Hilty and M.D. Hercheui, "ICT and sustainable development, What kind of information society?," in What kind of information society? Governance, virtuality, surveillance, sustainability, resilience, Proceedings of 9th IFIP TC 9 International Conference, HCC9, and 1st IFIP TC 11 International Conference, J. Berleur, M.D. Hercheui, and L.M. Hilty, Eds., Brisbane. September 20-23, 2010, p. 227-235.

[6] J.W. Houghton, "ICT and the environment in developing countries: A review of opportunities and developments," in What kind of information society? Governance, virtuality, surveillance, sustainability, resilience, Proceedings of 9th IFIP TC 9 International Conference, HCC9, and 1st IFIP TC 11 International Conference, J. Berleur, M.D. Hercheui, and L.M. Hilty, Eds., Brisbane, September 20-23, 2010, p. 236-247.

[7] T. Schauer, The sustainable information society - vision and risks. Vienna: The Club of Rome - European Support Centre, 2003.

[8] J. Servaes and N. Carpentier, Eds. Towards a sustainable information society. Deconstructing WSIS. Portland: Intellect, 2006.

[9] E. Ziemba, "The holistic and systems approach to a sustainable information society," Journal of Computer Information Systems, vol. 54, no 1, pp. 106-116, 2013.

[10] E. Ziemba, Eds. Towards a sustainable information society: People, business and public administration perspectives. Newcastle upon Tyne: Cambridge Scholars Publishing, 2016.

[11] C. Avgerou, "Discourses on ICT and development," Information Technologies and International Development, vol. 6, no 3, pp. 1-18, 2010.

[12] E. Curry and B. Donnellan, "Understanding the maturity of sustainable ICT," in Green business process management - Towards the sustainable enterprise, J. vom Brocke, S. Seidel, and J. Recker, Eds. Berlin: Springer, 2012, pp. 203-216.

[13] B. Donnellan, C. Sheridan, and E. Curry, "A capability maturity framework for sustainable information and communication technology," IT Professional, vol. 13, no 1, pp. 33-40, 2011.

[14] M.G. Guillemette and G. Pare, "Toward a new theory of the contribution of the IT function in organizations," MIS $Q$, (36:2), 2012, pp. 529-551.

[15] M.G. Guillemette and G. Paré, "Transformation of the information technology function in organizations: A Case study in the manufacturing sector," Canadian Journal of Administrative Sciences, vol. 29, pp. 177-190, 2012.

[16] S. Seidel, J. Recker, and J. vom Brocke, "Sensemaking and sustainable practicing: functional affordances of information systems in green transformations," MIS Q, vol. 37, no 4, pp. 1275-1299, 2013.

[17] R.T. Watson, M.C. Boudreau, A.J. Chen, and M. Huber, "Green IS: Building sustainable business practices," in Information systems, R.T. Watson, Ed. Athens: Global Text Project, 2008, pp. 247-261.

[18] V. Kodakanchi, E. Abuelyaman, M.H.S. Kuofie, and J. Qaddour, "An economic development model for IT in developing countries," The Electronic Journal of Information Systems in Developing Countries, vol. 28, no 7, pp. 1-9, 2006.

[19] J. Reardon, C. Miller, I. Vida, and I. Kim, "The effects of ethnocentrism and economic development on the formation of brand 
and ad attitudes in transitional economies," European Journal of Marketing, vol. 39, no 7/8, pp. 737-754, 2005.

[20] W.M. Olatokun, "Integration of policies and regulatory frameworks for the convergent ict industry in Nigeria," in Handbook of Research on Information Communication Technology Policy: Trends, Issues and Advancements, E.E. Adomi, Ed., Hershey: IGI Global, 2011, pp. 449-467.

[21] J.W. Ross and M.R. Vitale, "The ERP revolution: surviving vs thriving," Information Systems Frontiers, vol. 2, no 2, pp. 233-241, 2000.

[22] E. Ziemba, "The contribution of ICT adoption to the sustainable information society," Journal of Computer Information Systems, 2017, http://dx.doi.org/10.1080/08874417.2017.1312635

[23] J.D. Sachs, The age of sustainable development. New York: Columbia University Press, 2015.

[24] A.H. Huang, "A model for environmentally sustainable information systems development," Journal of Computer Information Systems, vol. 49, no 4, pp. 114-121, 2009.

[25] B. Moldan, S. Janoušková, and T. Hák, "How to understand and measure environmental sustainability: Indicators and targets," Ecological Indicators, vol. 17, pp. 4-13, 2012.

[26] M. Missimer, K.H. Robèrt, and G. Broman, "A strategic approach to social sustainability-Part 2: A principle-based definitions," Journal of Cleaner Production, vol. 149, no 1, pp. 42-52, 2017.

[27] Hameed, T. ICT as an enabler of socio-economic development. Daejeon: Information \& Communications University, 2015 http://www.itu.int/osg/spu/digitalbridges/materials/hameed-paper.pdf, (accessed: 12th June 2016)

[28] R. Khan, "How frugal innovation promotes social sustainability," Sustainability, vol. 8, no 10, paper 1034, 2016, doi:10.3390/su8101034.

[29] L.M. Hilty, E.K Seifert., and R. Treibert, Eds. Information systems for sustainable development. Hershey: Idea Group Publishing, 2005.
[30] P. Johnston, Towards a knowledge society and sustainable development: deconstructing the WSIS in the European policy context, in Towards a sustainable information society. Deconstructing WSIS, J, Servaes and N. Carpentier, Eds. Portland: Intellect, pp. 203-206, 2006,

[31] P.R. Hinton, C. Brownlow, I. McMurvay, and B. Cozens, SPSS Explained. East Sussex: Routledge, 2004.

[32] D. Gefen and D. Straub, "A practical guide to factorial validity using PLS-graph: Tutorial and annotated example," Communications of the Association for Information Systems, vol. 16, no 5, pp. 91-109, 2005.

[33] J. Hulland, "Use of Partial Least Squares (PLS) in strategic management research: A review of four recent studies," Strategic Management Journal, vol. 20, no 2, p. 195-204, 1999.

[34] T.A. Brown, Confirmatory factor analysis for applied research. Guilford Press, 2006.

[35] ŚCSI, Strategia rozwoju społeczeństwa informacyjnego województwa ślaskiego do roku 2015 [Strategy of information society development in Upper Silesia region]. Katowice: Sląskie Centrum Społeczeństwa Informacyjnego, 2009, http://www.e-slask.pl/article/strategia_rozwoju _spoleczenstwa_informacyjnego_wojewodztwa_slaskiego_do_roku_2 015, (accessed: 12th June 2016).

[36] J. Collis and R. Hussey, Business research. A practical guide for undergraduate and postgraduate students. New York: Palgrave Macmillan, 2003.

[37] J. Miles and M. Shevlin, Applying regression \& correlation. A quide for students and researchers. London: Sage Publication, 2007.

[38] R.F. Falk and N.B. Miller, A primer for soft modeling. Akron: The University of Akron Press, 1992.

[39] E. Ziemba, Eds. Czynniki sukcesu i poziom wykorzysatnia technologii informacyjno-komuniakcyjnych w Polsce [Success factors for and level of ICT adoption in Poland]. Warsaw: CeDeWu, 2015. 